\title{
Analisis Hukum Upaya Penanggulangan Tindakan Perundungan bagi Siswa - Siswi SMK Bina Latih Karya, Kota Bandar Lampung, Provinsi Lampung
}

\author{
Muhammad Syahri Ramadhan ${ }^{1 *}$, Yunial Laili Mutiari ${ }^{1,}$ Muhammad Zainul Arifin ${ }^{1}$, Irsan and Meria \\ Utama $^{1}$ \\ ${ }^{1}$ Jurusan Ilmu Hukum, Fakultas Hukum, Universitas Sriwijaya, Indonesia \\ *Correspondence author: msyahriramadhan@fh.unsri.ac.id; Phone: +6285273033622
}

Info Artikel: Diterima: 04 Desember 2020; Disetujui: 04 Mei 2021; Dipublikasi: 10 Mei 2021

\begin{abstract}
Perundungan atau biasa dikenal oleh masyarakat umum yaitu bullying, merupakan fenomena yang masih dianggap biasa bahkan dianggap suatu tindakan yang dapat menghibur bagi pelaku maupun korban atas tindakan perundungan tersebut. Hal inilah yang melatarbelakangi tim penyuluhan hukum Fakultas Hukum Universitas Sriwijaya mengadakan kegiatan penyuluhan hukum tentang Perundungan dalam Kalangan Remaja Di SMK Bina Latih Karya Bandar Lampung, Provinsi Lampung pada Sabtu, 24 Oktober 2020, Pukul 10.00 WIB sampai dengan Pukul 12.00 WIB dan dilakukan via daring (memanfaatkan aplikasi Zoom Meeting). Tujuan dari kegiatan penyuluhan hukum ini ialah memberikan pemahaman kepada siswa - siswi SMK Bina Latih Karya bahwa tindakan perundungan tidak hanya menyangkut ke permasalahan sosial tetapi juga berdampak kepada permasalahan hukum. Adapun manfaat dari kegiatan ini ialah dapat memberikan manfaat praktis dan manfaat sosial. Perundungan atau biasa dikenal oleh masyarakat umum yaitu bullying, tidak boleh lagi dianggap tindakan yang dapat menghibur bagi pelaku maupun korban maupun dianggap tradisi yang biasa saja. Para siswa - siswi juga memahami apa maksud dari aturan di dalam Undang - Undang Nomor 23 Tahun 2002 tentang perlindungan Anak dan Undang-Undang Republik Indonesia Nomor 35 Tahun 2014 Tentang Perubahan Atas Undang-Undang Nomor 23 Tahun 2002 Tentang Perlindungan Anak, setelah penyuluh menyampaikannya dengan cara memberi contoh sederhana tindakan perundungan yang biasa mereka terima.
\end{abstract}

Kata kunci: Analisis Hukum; Perundungan; SMK Bina Latih Karya

\section{Kutipan:}

Ramadhan, M.S., Mutiari, Y.L., Arifin, M.Z., Irsan., Utama, M. (2021). Analisis Hukum Upaya Penanggulangan Tindakan Perundungan bagi Siswa-Siswi SMK Bina Latih Karya, Kota Bandar Lampung, Provinsi Lampung. Sricommerce: Journal of Sriwijaya Community Services, 2(1):29-38.

DOI: https://doi.org/10.29259/jscs.v2i1.30

\section{PENDAHULUAN}

Perkara perundungan ataupun biasa yang diketahui dengan bullying dikala ini telah masuk dalam tahap mengkhawatirkan. Kalangan masyarakat mulai dari anak - anak hingga dewasa menjadikan sarana internet terutama platform di sosial media seperti twitter, facebook, instagram, serta fasilitas sosial media yang lain sebagai kebutuhan dasar dalam kehidupannya. Derasnya gelombang pemanfaatan media sosial ini menyebabkan permasalahan perundungan paling utama untuk anak- anak rentan untuk terjadi (Ramdhani, 2016). Perundungan ialah perilaku ingin menyakiti yang direalisasikan dalam aksi sehingga menimbulkan seseorang atau kelompok merasakan dampak negatif atas aksi tersebut (Saimima \& Rahayu, 2020). Tindakan ini mayoritas dilakukan oleh seseorang atau kelompok yang merasa mempunyai kelebihan fisik atau faktor 
lainnya seperti status sosial terhadap seseorang atau kelompok yang dianggap mempunyai rendah dibandingkan dirinya. Di samping itu, pelaku yang melakukan tindakan perundungan tersebut, mempunyai rasa tidak bersalah atas tindakan yang dilakukannya (Ponny Retno Astuti, 2008).

Realitas tindak kekerasan yang dialami kalangan anak - anak merupakan realitas yang sudah sering kali didengar bahkan dilihat. Peradigma masyarakat saat ini mengasumsikan bahwa kekerasan ialah suatu tindakan kejahatan yang berkaitan fisik saja, padahal ada suatu tindakan kekerasan yang tidak jauh berbahaya dibandingkan dengan kekerasan fisik yaitu kekerasan terhadap psikis (Rachmatan \& Rayyan, 2018). Informasi atau berita di media massa baik media cetak maupun media elektronik, tidak dapat dipungkiri banyak menyampaikan informasi tindak kekerasan terhadap hal - hal fisik seperti adanya kasus penganiayaan di sekolah, tawuran antar kelompok anak sekolah yang satu dengan kelompok sekolah lainnya. Selain tawuran antar pelajar sebenarnya ada bentuk-bentuk perilaku agresif atau kekerasan yang mungkin sudah lama terjadi di sekolah-sekolah, namun tidak mendapat perhatian, bahkan mungkin tidak dianggap sesuatu hal yang serius. Misalnya bentuk intimidasi dari teman-teman atau pemalakan, pengucilan diri dari temanya, sehingga anak jadi malas pergi ke sekolah karena merasa terancam dan takut, sehingga dapat menimbulkan depresi yang cukup berat sehingga menganggu aktivitas belajar di kelas (Joeragan, 2020).

Perundungan atau juga biasa dikenal bullying merupakan perilaku manusia yang melakukan serangan psikis dengan lisan dari si pelaku terhadap orang lain. Fenomena semacam ini tentunya akan memberikan dampak negatif yaitu menganggu ketenangan jiwa bagi korban perundungan tersebut. Mulai dari mengumpat, mengancam hingga intimidasi adalah realitas yang sering dilakukan dan kebanyakan yang menjadi korban ialah anak - anak. Jika fenomena sudah dipandang sebagai kebiasaan atau tradisi yang biasa, maka akan berdampak kepada degradasinya mental para anak yang notabene merupakan pewaris generasi bangsa (Ponny Retno Astuti, 2008).

Di era keterbukaan informasi sebagai konsekuensi kemajuan ilmu pengetahuan teknologi memang harus diterima sebagai suatu keniscayaan. Segala informasi baik yang bermuatan nasional hingga internasional sangat mudah didapatkan dengan memanfaatkan perangkat media sosial yang ada seperti facebook, instagram, twitter dan semacamnya (Ramadhan, 2021). Pemanfaatan fasilitas digital bukan berarti tidak mempunyai efek negatif, mengingat informasi yang disampaikan tersebut sangat terbuka sekali dan sukar untuk difilter oleh lembaga pemerintah, maka konsekuensi mendapatkan informasi negatif berupa tindakan kekerasan, terorisme, penganiaayaan dapat dengan mudah didapatkan oleh para penikmat perangkat media sosial (Ramadhan, 2021). Bahkan, sudah banyak program - program televisi, meskipun sudah berada dalam pengawasan Komisi Penyiaran Indonesia (KPI), menyajikan program - program televisi seperti sinetron bahkan acara komedi yang masih disertai dengan aksi kekerasan, saling mengumpat dan bentuk intimidasi lainnya. Tontonan semacam ini tentunya tidak tepat apalagi untuk kalangan anak - anak yang masih di bawah umur. Berita hingga program televisi yang masih memenuhi unsur kekerasan dan tidak melalui proses sensor yang ketat akan menyebabkan para penonton terutama kalangan anak - anak cenderung meniru atas apa yang mereka lihat atau baca. Maka dari itu, di era keterbukaan informasi ini pemerintah sudah menyiapkan regulasi, salah satunya ialah Undang - Undang Nomor 11 Tahun 2008 tetang Informasi dan Transaksi Elektronik. Upaya untuk menghindarkan atau meminimalisir tindakan perundungan di kalangan anak baik dalam ruang lingkup keluarga, teman hingga di lingkungan sekolah, juga harus digencarkan mulai dari mengoptimalkan regulasi yaitu Undang - Undang Nomor 32 tahun 2002 tentang Perlindungan Anak dan Undang-Undang Republik Indonesia Nomor 35 Tahun 2014 Tentang Perubahan Atas Undang-Undang Nomor 23 Tahun 2002 Tentang Perlindungan Anak hingga tahap sosialisasi yaitu seperti melakukan penyuluhan hukum ke sekolah tentang bahaya tindakan perundungan(Joeragan, 2020).

Hal inilah yang melatarbelakangi tim penyuluhan hukum Fakultas Hukum Universitas Sriwijaya mengadakan kegiatan penyuluhan hukum tentang Perundungan dalam Kalangan Remaja Di SMK Bina Latih Karya Bandar Lampung, Provinsi Lampung. Kegiatan penyuluhan ini sendiri dilakukan melalui via daring yaitu dengan memanfaatkan aplikasi Zoom Cloud Meeting. Hal ini dikarenakan pelaksanaan kegiatan dilakukan dalam situasi pandemi virus Covid - 19 dan harus mengikuti tata 
tertib pembelajaran yang sudah ditetapkan pemerintah yaitu harus melalui metode pembelajaran via online. Melalui kegiatan ini, besar harapannya jika siswa - siswi di SMA Bina Latih Karya Bandar Lampung untuk menjauhi tindakan perundungan, demi mewujudkan kemajuan mental anak bangsa yang kuat dan berkualitas. Mengingat keutuhan dan keharmonisan dalam anggota masyarakat dapat terwujud dengan tidak adanya budaya saling mengumpat, intimidasi dan semacamnya (Rachmatan \& Rayyan, 2018).

Tujuan dari kegiatan penyuluhan hukum ini ialah memberikan pemahaman kepada siswa siswi SMK Bina Latih Karya bahwa tindakan perundungan tidak hanya menyangkut ke permasalahan sosial tetapi juga berdampak kepada permasalahan hukum. Adapun manfaat dari kegiatan ini ialah dapat memberikan manfaat praktis dan sosial. Manfaat praktisnya ialah siswa siswi SMK Bina Latih Karya mengetahui bahwa tindakan perundungan tidak hanya akan memberi efek buruk bagi korban terutama dari kalangan anak - anak, tetapi hal tersebut juga memberikan efek sanksi hukum bagi pelakunya dikarenakan anak - anak sudah mendapat perlindungan hukum sebagaimana diatur dalam Undang - Undang Nomor 32 tahun 2002 tentang Perlindungan Anak dan Undang-Undang Republik Indonesia Nomor 35 Tahun 2014 Tentang Perubahan Atas UndangUndang Nomor 23 Tahun 2002 Tentang Perlindungan Anak. Manfaat sosialnya ialah menjadikan siswa - siswi SMK Bina Latih Karya Bandar Lampung sebagai bagian agent of change yang menganggap tindakan perundungan merupakan tradisi atau kebiasaan yang harus dihilangkan, demi terciptanya ketentraman dan kesejahteraan masyarakat.

\section{STUDI PUSTAKA}

\subsection{Pengertian Perundungan}

Tindakan perundungan adalah suatu istilah yang secara mayoritas masyarakat masih belum mengetahui definisinya, padahaln aktivitas perundungan ini merupakan kegiatan yang sudah seringkali terjadi di tengah - tengah masyarakat terutama di kalangan anak remaja di sekolah. Perundungan ini sebenarnya tidak hanya dijadikan sebagai masalah serius di kalangan nasional tetapi juga termasuk dalam kalangan dunia internasional (Soedjatmiko et al., 2016). Perundungan merupakan pemanfaatan daya kekuatan fisik atau mental seseorang atau kelompok yang disalahgunakan terhadap pihak yang mempunyai fisik atau mental yang lemah. Hal semacam ini tentunya akan memberi dampak negatif tidak hanya kepada korban tetapi juga pelaku. Dari segi pelaku tentu saja, kebiasaan melakukan perundungan akan menimbulkan potensi bahwa pelaku perundungan atau biasa disebut bully tersebut akan menjadi pelaku kejahatan yang lebih berat seperti pembunuh atau pemerkosa. Dari segi korban, pihak korban akan mengalami depresi yang begitu berat, hilang harapan untuk menjalani kehidupan, yang pada ujungnya nekat untuk melakukan tindakan bunuh diri (Sejiwa, 2008).

\subsection{Bentuk - Bentuk Perilaku Perundungan}

Asumsi masyarakat yang berkembang saat ini tindakan perundungan hanya beroerientasi kepada tindakan secara kekerasan fisik, padahal bentuk - bentuk dari perundungan terdiri dari beberapa kategori yaitu perundungan fisik; perundungan non-fisik; dan perundungan psikologis atau mental. Perundungan fisik ini pada dasarnya tindakan pelaku terhadap korban tersebut memang dapat sekilas terlihat dengan sangat jelas dikarenakan bentuk penyerangan yang dilakukan ialah berkaitan dengan fisik atau bagian tubuh korban, contoh misalnya menjambak, menampar dan meludahi. Perundungan non-fisik ialah tindakan pelaku terhadap korban tersebut dapat ditangkap dengan indra pendengaran oleh orang lain, misalnya ialah mengumpat, memaki, dan menghina di depan umum. Adapun perundungan psikologis atau mental ialah tindakan perundungan yang paling berbahaya dibanding dengan bentuk perundungan lainnya karena kadang diabaikan oleh beberapa orang. Bentuk perundungan mental/psikologis antara lain: memandang sinis, memandang penuh ancaman, mendiamkan, mengucilkan, memelototi, dan mencibir (Widya Ayu Sapitri, 2020).

Dari berbagai kategori perundungan yang sudah disebukan penulis di atas, perundungan yang 
seringkali terjadi dan dianggap sepele oleh masyarakat ialah perundungan non - fisik atau verbal. Serangan verbal yang dilakukan oleh kalangan anak atau remaja seperti mengumpat dan memaki dengan menyebut nama binatang atau orang tua korban, adalah fenomena yang sudah dianggap biasa saja saat ini. Padahal hal ini, jika dibiarkan begitu saja maka akan memberikan dampak yang berbahaya bagi perkembangan mental baik dari pelaku maupun korban. Biasanya bentuk perundungan nonfisik atau verbal ini sering digunakan oleh kalangan perempuan, meksipun dari pihak laki - laki juga melakukan perundungan secara verbal (Zakiyah et al., 2017). Tidak hanya itu, selain perundungan verbal, perundungan psikologis atau mental juga biasanya dilakukan oleh pihak perempuan seperti menyebarkan fitnah atau rumor yang tidak benar tentang korban sehingga berlanjut kepada tindakan perundungan lainnya seperti mengucilkan, mendiskriminasikan atau mendiskredikat korban dari pusaran kelompok teman - temannya. Adapun dari pihak laki - laki, hal yang dominan biasa dilakukan ialah melakukan perundungan fisik, seperti memukul, menjambak, menampar atau menginjak kaki temannya. Bentuk perundungan ini biasa dilakukan oleh pihak laki - laki dikarenakan paradigma masyarakat dalam menilai kuat atau tidaknya sosok dari laki - laki, hal yang pertama dinilai ialah kondisi fisik dari laki - laki tersebut (Widya Ayu Sapitri, 2020).

\subsection{Faktor-faktor yang menimbulkan tindakan perundungan}

Tindakan perundungan yaitu tindakan penyalahgunaan kekuasaan dari pelaku terhadap korban baik dari segi fisik, non-fisik/verbal, maupun mental/psikis pada dasarnya tidak hanya dipengaruhi dari faktor natural. Unsur natural disini maksudny adalah perilaku atas tindakan perundungan tersebut memang sudah karakteristik dari pelaku sejak lahir. Perundungan dapat juga ditimbulkan dari beberapa faktor, antara lain:

\section{a. Faktor dari keluarga}

Tidak mengherankan jika terdapat adagium yang mengatakan keluarga adalah sekolah atau madrasah pertama bagi anak. Hal ini dikarenakan lingkungan yang pertama kali dihadapi oleh manusia dalam melakukan hubungan interaksi sosial, dimulai dari lingkungan keluarga. Maka dari itu, terwujudnya karakter anak menjadi seorang pelaku bullying (bully) atau tidak, tergantung dengan sistem pola asuh yang diterapkan keluarganya. Kebebasan dalam bertindak yang dilakukan oleh si anak, tanpa diiringi dengan pengawasan yang bijak dari orang tua, akan berimplikasi kepada anak tersebut akan menjadi manja dan mempunyai hasrat untuk memaksakan segala keinginannya (Tang et al., 2020). Hal ini tentulah bukanlah sesuatu yang baik dikarenakan suatu kebebasan tanpa diiringi dengan pengawasan dari orang tua, akan menyebabkan si anak tidak mempunyai arah tujuan hidup sehingga si anak mengalami kebingungan, termasuk dalam hal tindakan perundungan yang dia lakukan tersebut, dianggap hal yang biasa dikarenakan tidak ada orang tua yang pernah memberi nasehat tentang bentuk - bentuk tindakan perundungan tersebut (Zakiyah et al., 2017). Sebaliknya, jika kebebasan atas setiap tindakan yang dilakukan si anak selalu dikekang, maka hal tersebut jugg merupakan hal yang tidak baik. Pengekangan secara ekstra terhadap anak apalagi dipenuhi unsur kekerasan, tentunya akan berdampak negatif bagi perkembangan mental anak itu sendiri. Pola asuh yang keras dilakukan oleh orang tua, secara otomatis akan ditiru si anak dimana dia akan juga berperilaku kasar kepada teman - temannya (Zakiyah et al., 2017).

\section{b. Faktor dari pergaulan}

Setiap anak pada hakekatnya mempunyai rasa keinginan untuk bermain. Untuk memenuhi keinginan tersebut maka dia akan selalu berupaya mencari teman sepermainan. Lingkungan teman sepermainan ini sendiri juga menentukan perkembangan perilaku dari anak - anak itu sendiri (Sukardi et al., 2015). Setiap tindakan yang dilakukan oleh si anak, tentunya akan dicontoh atau ditiru oleh teman - temannya yang lain. Tindakan perundungan yang dilakukan satu temannya, tentunya akan dilakukan juga oleh teman - temannya yang lain. Tindakan perundungan tersebut dianggap suatu tradisi yang dianggap biasa dan lumrah untuk dilakukan. Demi meningkatkan 
eksistensi diri di antara teman - temannya, maka si pembully selalu berusaha meningkatkan kapasitas tindakan perundungannya tersebut. Ada beberapa faktor yang menyebabkan seorang individu atau kelompok melakukan perundungan fisik, nonfisik maupun psikis, antara lain ialah (Siswati \& Widayanti, 2019):

1. Perasaan berhak

Berkaitan dengan kekuatan dan kekuasaan yang dimiliki anak untuk mengendalikan, mengontrol, bahkan menindas dan menyiksa orang lain

2. Fanatisme pada perbedaan

Perbedaan yang ada baik fisik, agama, kemampuan ekonomi, hingga kemampuan akademik dipandang sebagai kelemahan yang tidak pantas untuk mendapatkan penghargaan.

3. Suatu kemerdekaan untuk mengecualikan

Anak dengan leluasa dan bebas untuk mengkotak-kotakkan untuk memisahkan seseorang atau kelompok dari yang lain dengan anggapan bahwa mereka tidak sejajar dengan yang lain.

\section{METODE}

Khalayak sasaran dalam kegiatan penyuluhan hukum ini ialah siswa - siswi SMK Bina Latih Karya Bandar Lampung, Provinsi Lampung,yang berasal dari kelas XII sejumlah 40 (empat puluh) orang. Adapun dalam kegiatan tersebut juga didampingi satu orang guru yang turut serta dalam kegiatan penyuluhan hukum bersama tim penyuluhan hukum Fakultas Hukum Universitas Sriwijaya. Merujuk kepada tipe kegiatan penyuluhan hukum ini, realisasi aktivitas penyuluhan ini dilakukan dengan beberapa metode, diantaranya adalah :

\section{a. Ceramah}

Yaitu penyuluh dalam hal ini Dosen Fakultas Hukum Universitas Sriwijaya menyampaikan secara langsung materi kepada siswa - siswi SMK Bina Latih Karya Bandar Lampung, dengan cara tatap muka via daring dengan menggunakan aplikasi Zoom.

b. Diskusi dan sharing ilmu

Kegiatan ceramah apabila dari penyuluh selesai dilakukan, kemudian dilaksanakan sesi tanya jawab antara tim penyuluh dengan siswa - siswi SMK Bina Latih Karya Bandar Lampung. Kemudian siswa - siswi SMK Bina Latih Karya Bandar Lampung akan diajak kembali berdiskusi dengan diskusi interaktif terhadap pertanyaan maupun jawaban yang sudah disampaikan tim penyuluh, guna melihat seberapa besar antusiasme dan tingkat kritis siswa - siswi terhadap materi yang disampaikan tersebut.

Faktor-faktor yang harus diperhatikan agar penyuluhan hukum dapat berjalan dengan baik adalah dengan memahami para siswa - siswi tersebut serta kemampuan berkomunikasi mereka yang baik. Sehingga siswa - siswi dapat memahami dan menerima materi yang dipaparkan dengan baik. Dalam penyuluhan ini, keberhasilannya dipengaruhi oleh banyak faktor. Diantaranya dorongan dari pihak sekolah terutama guru mempunyai peran besar dalam membimbing siswa siswinya untuk mencegah tindakan perundungan di sekolah.

\section{HASIL DAN PEMBAHASAN}

Pada mulanya persiapan yang dilakukan ini dengan mempersiapkan semua bahan - bahan yang berkaitan dengan kegiatan, yaitu pegumpulan literatur dengan cara studi kepustakaan mulai dari buku - buku, artikel di jurnal ilmiah, situs website resmi miliki pemerintah, media massa baik media cetak maupun media online yang mempunyai korelasi dengan topik penyuluhan yang disampaikan oleh tim. Mengingat situasi pandemi covid - 19 saat ini dan pemerintah pusat membuat kebijakan pelaksanaan kegiatan belajar mengajar melalui daring atau online. Tim penyuluhan melaksanakan kegiatan tersebut pada Sabtu, 24 Oktober 2020, Pukul 10.00 WIB sampai dengan Pukul 12.00 WIB melalui aplikasi Zoom Meetings. Adapun peserta kegiatan ialah 
guru pendamping dan siswa/siswi SMK Bina Latih Karya Bandar Lampung, Provinsi Lampung. Perundungan atau biasa dikenal oleh masyarakat umum yaitu bullying, merupakan fenomena yang masih dianggap biasa bahkan dianggap suatu tindakan yang dapat menghibur bagi pelaku maupun korban atas tindakan perundungan tersebut. Paradigma yang menganggap perundungan merupakan kebiasaan yang ada di tengah kalangan masyarakat, harus segera dihilangkan. Hal ini mengingat perundungan tersebut dapat memberikan dampak psikis, sosial di masyarakat bahkan dampak fisik bagi korbannya sangat dimungkinkan dapat terjadi (Joeragan, 2020).

Terkait persoalan di atas, maka ditemukan masalah - masalah yang ditemukan pada saat kegiatan penyuluhan tersebut, antara lain:

a. Masih kurangnya pemahaman mengenai terminologi maupun bahaya yang ditimbulkan dari tindakan perundungan atau bully tersebut bagi pihak pelaku maupun korban.

b. Pemahaman orang tua mengenai tindakan yang harus dilakukan ketika anaknya menjadi korban perundungan, masih begitu kurang

c. Eksistensi Undang - Undang Nomor 23 Tahun 2002 tentang perlindungan Anak dan Undang - Undang Republik Indonesia Nomor 35 Tahun 2014 Tentang Perubahan Atas Undang - Undang Nomor 23 Tahun 2002 Tentang Perlindungan Anak sebagai landasan yuridis normatif dalam mengatur persoalan perundungan bagi anak, masih belum optimal dalam aspek implementasinya

d. Pihak sekolah masih bingung dalam melaksanakan langkah - langkah hukum dalam menangani kasus perundungan, baik langkah hukum yang bersifat preventif maupun represif

e. Kurangnya pemahaman mengenai sanksi yang dapat diterima bagi pelaku perundungan

f. Kurangnya pemahaman dari orang tua mengenai tindakan yang dapat dilakukan agar anak tidak menjadi pelaku perundungan

g. Respon masyarakat atas tindakan perundungan yang terjadi di kawasan sekitar sekolah masih kurang, dikarenakan mereka sendiri belum memahami secara komprehensif mengenai tindakan perundungan.

Berdasarkan permasalahan yang dipaparkan di atas, Tim penyuluhan Fakultas Hukum Universitas Sriwijaya melakukan sosialisasi Penyuluhan Hukum Tentang Perundungan Dalam Kalangan Remaja Di SMK Bina Latih Karya Bandar Lampung, Provinsi Lampung dengan memberikan pengetahuan melalui paparan (presentasi), diskusi, maupun tanya jawab terkait

a. Terminologi maupun bahaya yang ditimbulkan dari tindakan perundungan atau bully tersebut bagi pihak pelaku maupun korban.

b. Jenis - jenis perundungan

c. Perlindungan hukum bagi korban yang mengalami tindakan perundungan

d. Upaya hukum yang dapat dilakukan mulai dari upaya preventif hingga represif (penerapan sanksi) yang sudah diatur dalam regulasi sebagaimana diatur dalam UU No. 35 Tahun 2014 tentang perlindungan Anak dan Undang-Undang Republik Indonesia Nomor 35 Tahun 2014 Tentang Perubahan Atas Undang-Undang Nomor 23 Tahun 2002 Tentang Perlindungan Anak

e. Peran serta pihak sekolah, orang tua, masyarakat khususnya para siswa dalam menanggulangi kasus tindakan perundungan yang terjadi di sekitarnya.

Respon yang diberikan oleh peserta dalam kegiatan penyuluhan hukum sangat baik, meskipun kegiatan tersebut dilakukan via daring. Antusiasme para siswa - siswi dalam mengikuti kegiatan penyuluhan hukum ini dapat dilihat pada diskusi dua arah dan sesi tanya jawab yang dilakukan selama proses kegiatan berlangsung. Pada sesi tanya jawab diberikan kesempatan dua orang bertanya, dan realitanya di setiap sesi terdapat lebih dari dua orang yang bertanya kepada tim penyuluh. Respon yang sangat baik juga dapat terlihat ketika tim penyuluh menyampaikan sesi umpan balik, dengan mengajukan 5 (lima) pertanyaan yang diambil dari materi yang disampaikan ketika proses penyuluhan hukum berlangsung secara acak kepada peserta penyuluhan. Lima pertanyaan yang disampaikan tim penyuluh tersebut, berhasil dijawab dengan baik oleh peserta 
penyuluhan. Hal yang menarik dalam diskusi dengan para peserta ialah, fenomena tindakan perundungan yang dilakukan atau dirasakan, mayoritas berasal dari lingkungan pertemanan siswa - siswi SMK Bina Latih Karya itu sendiri. Bahkan, mereka akhirnya mengetahui kebiasaan melakukan tindakan perundungan merupakan bagian dari definisi kekerasan yang diatur dalam Pasal 1 angka 15a yang menyebutkan: "Kekerasan adalah setiap perbuatan terhadap Anak yang berakibat timbulnya kesengsaraan atau penderitaan secara fisik, psikis, seksual, dan/atau penelantaran, termasuk ancaman untuk melakukan perbuatan, pemaksaan, atau perampasan kemerdekaan secara melawan hukum (Undang-Undang Republik Indonesia Nomor 35 Tahun 2014 Tentang Perubahan Atas Undang-Undang Nomor 23 Tahun 2002 Tentang Perlindungan Anak, 2014)."

\section{Evaluasi Kegiatan}

Informasi yang diberikan dalam penyuluhan ini disampaikan dalam bentuk power point yang dihubungan melalui zoom meeting. Metode kegiatan dalam penyuluhan ini merupakan metode baru yaitu dilaksanakan melalui media daring, maka dua hari sebelum hari - $\mathrm{H}$ kegiatan dilaksanakan, tim penyuluh sudah membuatkan dan memberikan ID Zoom beserta pasword yang kepada guru pendamping dan siswa - siswi SMK Bina Latih Karya Bandar Lampung. Tidak ditemukan kendala atau hambatan dalam memanfaatkan aplikasi zoom meeting dalam melaksanakan kegiatan penyuluhan tersebut. Mengingat para siswa - siswi tersebut memang sudah melaksanakan kegiatan belajar - mengajar via daring sebelum kegiatan penyuluhan hukum berlangsung. Jadi, Para siswa - siswi tersebut pada dasarnya memang sudah mempunyai kemampuan dalam memanfaatkan beberapa media yang digunakan untuk kegiatan belajar mengajar via daring, salah satunya aplikasi Zoom Meeting.

Tahapan selanjutnya ialah menyampaikan materi kepada para siswa - siswi SMK Bina Latih Karya antara lain adalah dampak negatif dari perundungan, cara mencegah atau menghindari perundungan, pentingnya peran keluarga dalam memberikan pendidikan dini kepada anak untuk tidak melakukan perundungan, pentingnya peran keluarga untuk memberikan perlindungan ketika anaknya menjadi korban perundungan, peran pihak sekolah dalam mencegah perundungan, langkah dan kebijakan apa yang dapat dilakukan oleh pihak sekolah ketika ada siswa di sekolahnya ada yang menjadi pelaku dan korban perundungan, sanksi hukum yang dapat dikenakan bagi pelaku perundungan dan lain sebagainya. Hal yang tidak boleh dikesampingkan juga ialah sosialisasi Undang - Undang Nomor 23 Tahun 2002 tentang perlindungan Anak dan UndangUndang Republik Indonesia Nomor 35 Tahun 2014 Tentang Perubahan Atas Undang-Undang Nomor 23 Tahun 2002 Tentang Perlindungan Anak. Tim penyuluhan hukum mengharapkan kepada pihak sekolah untuk gencar mengsosialisasikan regulasi tersebut dikarenakan bentuk pencegahan dari timbulnya tindakan perundungan merupakan bagian dari perlindungan hukum untuk siswa siswi itu sendiri. Sebagaiman dalam pasal 1 angka 2 menyebutkan "Perlindungan anak adalah segala kegiatan untuk menjamin dan melindungi anak dan hak-haknya agar dapat hidup, tumbuh, berkembang, dan berpartisipasi, secara optimal sesuai dengan harkat dan martabat kemanusiaan, serta mendapat perlindungan dari kekerasan dan diskriminasi (Undang-Undang Republik Indonesia Nomor 23 Tahun 2002 Tentang Perlindungan Anak, 2002). Untuk bagi siswa - siswi itu sendiri, materi yang diberikan diharapkan dapat menjadi sumber penanaman nilai moral bagi mereka, agar supaya dapat memfilter segala aktivitas yang diketahui, dirasakan dan diterima oleh dirinya. Hal ini demi menjaga karakteristik para siswa - siswi yang bermental kuat, selalu berpikir positif dan terhindar dari sikap intimidatif.

Tahapan Selanjutnya adalah diskusi dan tanya jawab mengenai tindakan perundungan, baik dari sisi peraturan perundang - undangan maupun dari peran serta yang dapat dilakukan oleh siswa. Tahapan ini merupakan tahapan evaluasi yaitu untuk mengetahui perubahan sikap dan peningkatan pengetahuan siswa terhadap aturan hukum dan perilaku yang berkaitan dengan kasus perundungan. Evaluasi yang dilakukan ialah dengan cara memberikan contoh - contoh kasus perundungan yang begitu sederhana dan biasa dilakukan oleh setiap orang. Alasannya supaya para peserta dapat memamahami secara komprehensif setiap materi yang disampaikan 
oleh penyuluh. Mengingat penyuluh mengaitkan persoalan perundungan dengan aspek peraturan perundang - undangan yaitu Undang - Undang Nomor 23 Tahun 2002 tentang perlindungan Anak dan Undang-Undang Republik Indonesia Nomor 35 Tahun 2014 Tentang Perubahan Atas UndangUndang Nomor 23 Tahun 2002 Tentang Perlindungan Anak. Jika hal tersebut, hanya menyampaikan isi dari Pasal - Pasal tersebut, ada kemungkinan para siswa - siswai tidak mengerti bahkan memahami maksud isi aturan tersebut.
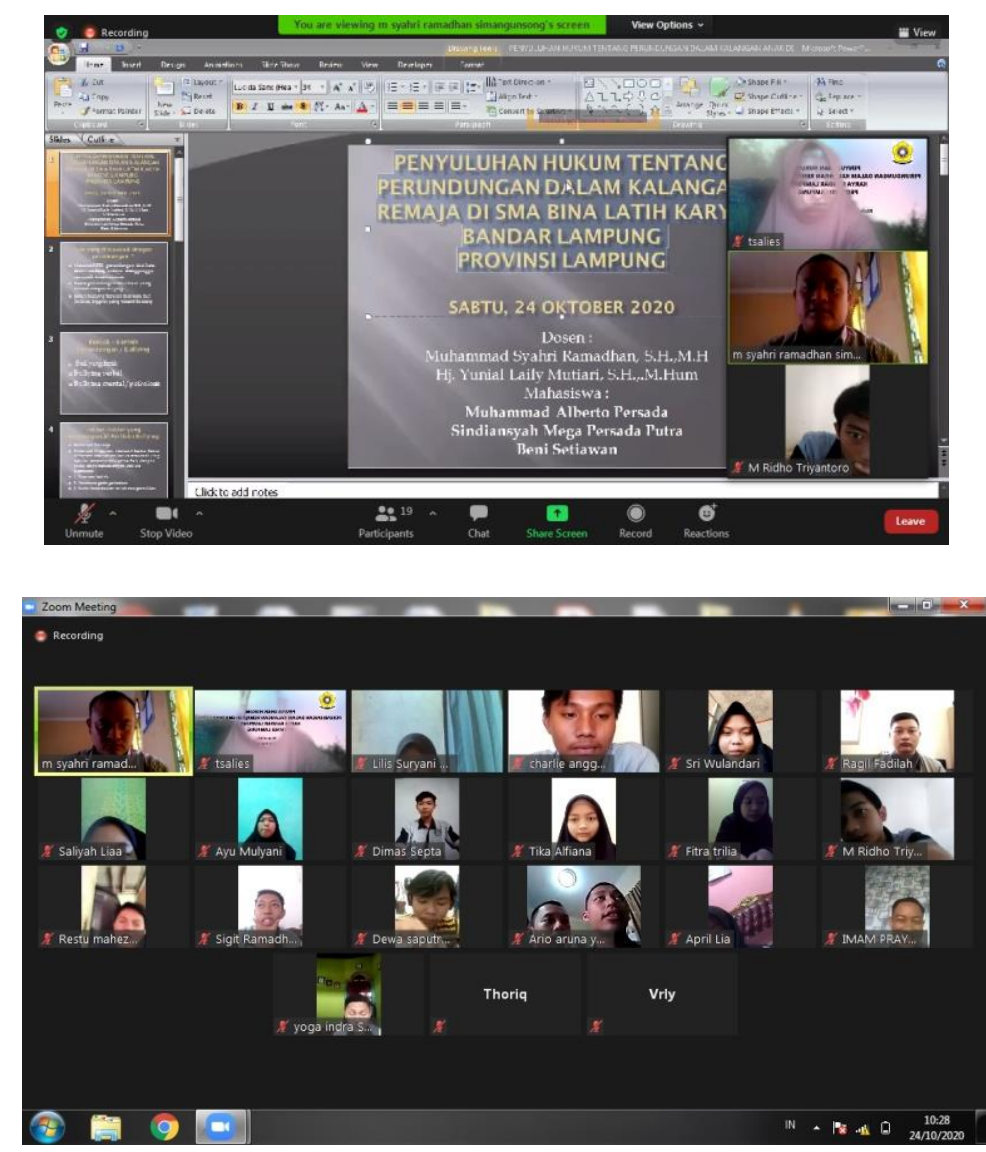

Gambar 1: Kegiatan penyuluhan hukum yang dilakukan via aplikasi zoom cloud

Dari serangkaian kegiatan penyuluhan di atas, tim penyuluh dapat melihat bahwa para siswa - siswi tidak mengetahui jenis - jenis dan dampak dari adanya tindakan perundungan serta aturan hukum terkait tindakan perundungan. Para siswa - siswi, menganggap tindakan perundungan yang biasa dilakukan merupakan tradisi yang tidak harus dipermasalahkan dan dianggal tidak menimbulkan konsekuensi sosial maupun hukum. Maka dari itu, materi penyuluhan hukum mengenai perundungan sangat penting untuk disampaikan kepada siswa - siswi SMK Bina Latih Karya Bandar Lampung, karena fase usia mereka masih dalam tahap usia labil, sehingga rentan untuk menjadi korban dan pelaku perundungan. Hasilnya para peserta sudah memulai memahami tentang bahaya tindakan perundungan dan aturan hukum terkait tindakan negatif tersebut. Para siswa - siswi juga memahami apa maksud dari aturan di dalam Undang - Undang Nomor 23 Tahun 2002 tentang perlindungan Anak dan Undang-Undang Republik Indonesia Nomor 35 Tahun 2014 Tentang Perubahan Atas Undang-Undang Nomor 23 Tahun 2002 Tentang Perlindungan Anak, setelah penyuluh menyampaikannya dengan cara memberi contoh sederhana tindakan perundungan yang biasa mereka lakukan. Pentingnya keterbukaan dalam komunikasi yang positif antara para siswa, para siswa dan guru, maupun para siswa dan orang tua adalah salah satu kunci untuk mengubah paradigma bahwa perundungan bukanlah suatu tradisi atau kebiasaan yang harus diterima. Penerapan tata krama dan berbicara sopan terhadap sesama teman maupun orang yang lebih tua mempunyai peran besar dalam menciptakan harmonisasi hubungan antara mereka. Di samping itu, pihak sekolah atau guru mengetahui bahwa upaya preventif lebih baik 
untuk dilakukan daripada upaya represif dalam menanggulangi kasus perundungan. Jika tindakan perundungan tersebut masih terjadi, maka proses penyelesaian nonlitigasi seperti musyawarah, mediasi dan semacamnya adalah langkah prioritas yang dilakukan pihak sekolah dalam mengatasi kasus perundungan yang terjadidi sekolahnya.

\section{KESIMPULAN}

Berdasarkan dari penyuluhan hukum yang diadakan tim penyuluhan hukum Dosen Fakultas Hukum Universitas Sriwijaya pada Sabtu, 24 Oktober 2020, Pukul 10.00 WIB sampai dengan Pukul 12.00 WIB dan dilakukan via daring (memanfaatkan aplikasi Zoom Meeting) terhadap siswa - siswi SMK Bina Latih Karya Bandar Lampung, Provinsi Lampung, maka terdapat beberapa kesimpulan yaitu Perundungan atau biasa dikenal oleh masyarakat umum yaitu bullying, merupakan fenomena yang masih dianggap biasa bahkan dianggap suatu tindakan yang dapat menghibur bagi pelaku maupun korban atas tindakan perundungan tersebut, sudah tidak boleh lagi dianggap seperti itu lagi. Para siswa - siswi juga memahami apa maksud dari aturan di dalam Undang Undang Nomor 23 Tahun 2002 tentang perlindungan Anak dan Undang-Undang Republik Indonesia Nomor 35 Tahun 2014 Tentang Perubahan Atas Undang-Undang Nomor 23 Tahun 2002 Tentang Perlindungan Anak, setelah penyuluh menyampaikannya dengan cara memberi contoh sederhana tindakan perundungan yang biasa mereka terima. Para siswa - siswi mengetahui dan memahami kebiasaan melakukan tindakan perundungan merupakan bagian dari definisi kekerasan yang diatur dalam Pasal 1 angka 15a Undang-Undang Republik Indonesia Nomor 35 Tahun 2014 Tentang Perubahan Atas Undang-Undang Nomor 23 Tahun 2002 Tentang Perlindungan Anak, yang menyebutkan: "Kekerasan adalah setiap perbuatan terhadap Anak yang berakibat timbulnya kesengsaraan atau penderitaan secara fisik, psikis, seksual, dan/atau penelantaran, termasuk ancaman untuk melakukan perbuatan, pemaksaan, atau perampasan kemerdekaan secara melawan hukum."

Pihak sekolah dalam hal ini guru, akan gencar dalam melakukan sosialisasi Undang - Undang Nomor 23 Tahun 2002 tentang perlindungan Anak dan Undang-Undang Republik Indonesia Nomor 35 Tahun 2014 Tentang Perubahan Atas Undang-Undang Nomor 23 Tahun 2002 Tentang Perlindungan Anak, bagi para siswa - siswai SMK Bina Latih Karya. Pihak sekolah memahami bahwa mengsosialisasikan regulasi tersebut merupakan manifestasi dari upaya pencegahan dan mewujudkan perlindungan hukum bagi para siswa - siswi. Pentingnya keterbukaan dalam komunikasi yang positif antara para siswa, para siswa dan guru, maupun para siswa dan orang tua adalah salah satu kunci untuk mengubah paradigma bahwa perundungan bukanlah suatu tradisi atau kebiasaan yang harus diterima. Penerapan tata krama dan berbicara sopan terhadap sesama teman maupun orang yang lebih tua mempunyai peran besar dalam menciptakan harmonisasi hubungan antara mereka. Di samping itu, pihak sekolah atau guru mengetahui bahwa upaya preventif lebih baik untuk dilakukan daripada upaya represif dalam menanggulangi kasus perundungan. Jika tindakan perundungan tersebut masih terjadi, maka proses penyelesaian nonlitigasi seperti musyawarah, mediasi dan semacamnya adalah langkah prioritas yang dilakukan pihak sekolah dalam mengatasi kasus perundungan yang terjadidi sekolahnya.

\section{UCAPAN TERIMA KASIH}

Terima kasih kepada pihak pimpinan Fakultas Hukum Universitas Sriwijaya yang telah mendanai kegiatan pengabdian melalui dana PNBP Fakultas. Rasa terima kasih juga disampaikan kepada pihak siswa - siswai, kepala sekolah beserta para guru SMK Bina Latih Karya yang bersedia untuk bekerjama dalam merealisasikan kegiatan pengabdian ini.

\section{REFERENSI}

Undang-Undang Republik Indonesia Nomor 35 Tahun 2014 Tentang Perubahan Atas UndangUndang Nomor 23 Tahun 2002 Tentang Perlindungan Anak, (2014).

Joeragan. (2020). Bangkit, Ubah Perundungan Jadi Kekuatan (Winy Rifmawati (ed.); I). Makmood 
Publishing.

Ponny Retno Astuti. (2008). 3 Cara Meredam Bullying (I). PT. Gramedia Widasarana Indonesia.

Rachmatan, R., \& Rayyan, R. (2018). Harga Diri dan Perundungan Siber pada Remaja. INSAN Jurnal Psikologi Dan Kesehatan Mental, 2(2). https://doi.org/10.20473/jpkm.v2i22017.120-126

Ramadhan, M. S. (2021, April). Sudah Saatnya Meregulasi Digitalisasi Bisnis. Sriwijaya Post, 2. https://palembang.tribunnews.com/2021/04/05/sudah-saatnya-meregulasi-digitalisasibisnis?page $=4$

Ramdhani, N. (2016). Emosi Moral dan Empati pada Pelaku Perundungan-siber. Jurnal Psikologi, 43(1). https://doi.org/10.22146/jpsi.12955

Undang-Undang Republik Indonesia Nomor 23 Tahun 2002 Tentang Perlindungan Anak, Pub. L. No. 23 (2002).

Saimima, I. D. S., \& Rahayu, A. P. (2020). Anak Korban Tindak Pidana Perundungan (Cyberbullying) Di Media Sosial. Jurnal Kajian Ilmiah, 20(2), 125-136. https://doi.org/10.31599/jki.v20i2.102

Sejiwa. (2008). Bullying: Mengatasi Kekerasan di Sekolah dan Lingkungan (Ariobimo Nusantara (ed.)). PT Grasindo.

Siswati, \& Widayanti, C. G. (2019). Fenomenaabullyingdiisekolahhdasarrnegeriidii Semarang:: Sebuahhstudiideskriptiffff. Jurnal Psikologi Undip.

Soedjatmiko, S., Nurhamzah, W., Maureen, A., \& Wiguna, T. (2016). Gambaran Bullying dan Hubungannya dengan Masalah Emosi dan Perilaku pada Anak Sekolah Dasar. Sari Pediatri. https://doi.org/10.14238/sp15.3.2013.174-80

Sukardi, D., Syari'ah, F., Islam, D. E., Syekh, I., Cirebon, N., Perjuangan, J., \& Cirebon, P. S. (2015). Kajian Kekerasan Rumah Tangga Dalam Perspektif Hukum Islam Dan Hukum Positif. Didi Sukardi Kajian Kekerasan Rumah Tangga Mahkamah.

Tang, I., Supraha, W., \& Rahman, I. K. (2020). Upaya mengatasinya perilaku perundungan pada usia remaja. Jurnal Pendidikan Luar Sekolah, 14(2). https://doi.org/10.32832/jpls.v14i2.3804

Widya Ayu Sapitri. (2020). Cegah dan Stop Bullying Sejak Dini (Guepedia (ed.); I). Guepedia.

Zakiyah, E. Z., HUMAEDI, S., \& SANTOSO, M. B. (2017). FAKTOR YANG MEMPENGARUHI REMAJA DALAM MELAKUKAN BULLYING. Prosiding Penelitian Dan Pengabdian Kepada Masyarakat. https://doi.org/10.24198/jppm.v4i2.14352 